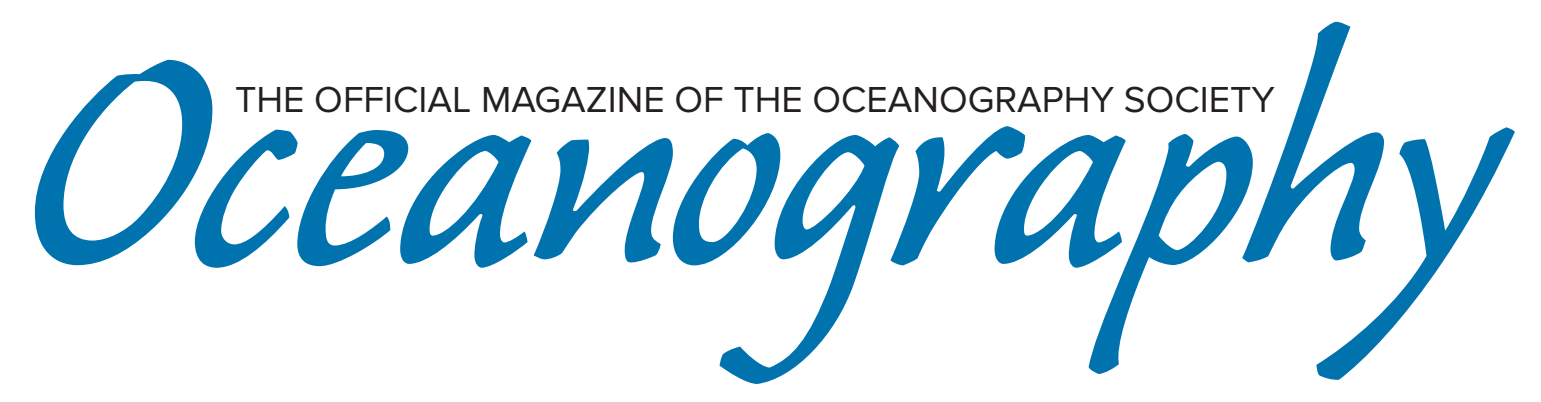

CITATION

Brewer, P.G., E.T. Peltzer, P.M. Walz, and W.J. Kirkwood. 2017. Creating the art of deepsea experimental chemistry with MBARI ROVs. Oceanography 30(4):48-59, https://doi.org/10.5670/oceanog.2017.423.

DOI

https://doi.org/10.5670/oceanog.2017.423

\title{
COPYRIGHT
}

This article has been published in Oceanography, Volume 30, Number 4, a quarterly journal of The Oceanography Society. Copyright 2017 by The Oceanography Society. All rights reserved.

USAGE

Permission is granted to copy this article for use in teaching and research. Republication, systematic reproduction, or collective redistribution of any portion of this article by photocopy machine, reposting, or other means is permitted only with the approval of The Oceanography Society. Send all correspondence to: info@tos.org or The Oceanography Society, PO Box 1931, Rockville, MD 20849-1931, USA. 


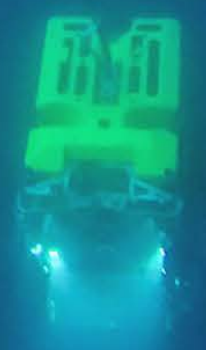

\section{Creating the Art of Deep-Sea Experimental Chemistry with MBARI ROVs}

By Peter G. Brewer, Edward T. Peltzer, Peter M. Walz, and William J. Kirkwood

ABSTRACT. Ocean chemistry has been almost exclusively based upon retrieving samples from the ocean for laboratory or shipboard analysis, or deploying sensors to recover natural signals. The ability to execute complex experiments in the deep ocean akin to the manipulations carried out in laboratories has largely been absent. In this paper, we review the progress made in manipulating and sensing complex gases, liquids, and solids in real time in the deep sea to advance understanding of natural processes. These experiments were made possible by access to the remarkable capabilities of Monterey Bay Aquarium Research Institute's (MBARI's) remotely operated vehicle and the skills of the operational teams. Here, we report on advances made in methane hydrate research and deep-ocean Raman spectroscopy, and on proposals for fossil fuel $\mathrm{CO}_{2}$ sequestration and on controlled ocean acidification studies. The skills necessary to advance this work have been made possible only by the joint efforts of engineers and scientists as envisaged by MBARI's founder. We note with some concern that in reporting progress here there were few antecedents to draw upon, so that the citations listed have a distinctly unbalanced look. Nonetheless, the impacts of the institute's work have been far-reaching. 


\section{INTRODUCTION}

David Packard was a great fan of PCAST-the President's Council of Advisors on Science and Technology. He had worked with this body during his time in the Department of Defense during the Reagan administration, and he had urged the Monterey Bay Aquarium Research Institute (MBARI) to pay attention to its reports as leading indicators of science directions of national importance. The 1997 PCAST report on the emerging federal energy research agenda was such a document (PCAST, 1997), and we studied it carefully. It was a remarkably adventurous plan; the report was chaired by John Holdren (later Science Advisor to President Obama, and the longest ever to serve in that role), and it recommended investigation of two possible large-scale ocean interventions. The first was to extract energy from the abundant deep-sea methane hydrate resources, and the second was to investigate the amelioration of climate change by capture of fossil fuel $\mathrm{CO}_{2}$ and disposing of it as a solid hydrate on the deep-sea floor.

It was at once clear to an ocean chemist that these two schemes would be expensive and unlikely to succeed. Moreover, the spectacle of large-scale injection of one gas to form a hydrate in the ocean, while simultaneously extracting another gas already in the solid hydrate form from the ocean, had a slightly manic flavor. Nonetheless, the simple fact that these two engineering themes involving ocean science-novel energy resources, and climate change avoidance-were high on the PCAST agenda spoke to the urgent need for clarification of options.

This research could not be done by posturing; it could only be tackled by clear and efficient experiments executed in the real ocean, not in the laboratory or on the computer. We resolved to attack these problems, but were from the outset keenly aware of the inherent contradictions. An MBARI paper (Brewer, 1997) had already analyzed the ocean chemistry consequences of the 1990 IPCC report that charted a future atmospheric
$\mathrm{CO}_{2}$ growth under the "business as usual" rubric. The projection was worrisome, indicating a drop in ocean $\mathrm{pH}$ of $\sim 0.4$ units and loss of some $55 \%$ of carbonate ion by the year 2100 . These disturbing data crystallized in specific form concerns voiced long before. In 1951, Rubey had noted in referring to the stores of geologic fuel that "if only $1 / 100$ of this buried carbon were suddenly added to the present atmosphere and ocean, many species of marine organisms would probably be exterminated." In his classic 1961 paper, Sillén had very carefully expressed concern that "the $\mathrm{pH}$ of the ocean is somewhat precarious," and in 1978, Brewer authored the first paper on direct detection of the increase in oceanic $\mathrm{CO}_{2}$.

Disposal of fossil fuel $\mathrm{CO}_{2}$ in the ocean could only add to this chemical stressbut with the purported benefit of slowing global warming. Which might be the better course?

\section{OCEAN DISPOSAL OF FOSSIL FUEL $\mathrm{CO}_{2}$}

The concept of ocean disposal of captured fossil fuel $\mathrm{CO}_{2}$ originated from Marchetti (1977). In that paper, it was pointed out that a large fraction of fossil fuel $\mathrm{CO}_{2}$ (today some 25\%) released to the atmosphere was rapidly transferred by gas exchange to the surface ocean, and that in the very long run, some $85 \%$ of all $\mathrm{CO}_{2}$ emissions would be absorbed by the ocean. Why not then avoid the atmospheric residence time step with the attendant global warming problems, and inject the gas directly into the deep sea? Issues of the technical challenge and cost of $\mathrm{CO}_{2}$ capture were glossed over, as was any sense of environmental harm to the ocean.

Our first attempt at executing a deepsea experiment manipulating liquid $\mathrm{CO}_{2}$ to form a hydrate $\left(910 \mathrm{~m}\right.$ depth, $3.9^{\circ} \mathrm{C}$ ) did not go well (Brewer et al., 1998); we attempted to use helium gas under pressure to push out the liquid $\mathrm{CO}_{2}$. We quickly discovered the very high compressibility of liquid $\mathrm{CO}_{2}$, and the quite high solubility of helium in the liquid.
We were welcomed into the strange phase behavior of exotic fluids and the need for engineering colleagues to design and construct systems that could actually work. But we were successful in detaching the hydrate-containing experimental unit from the vehicle and leaving it on the seafloor for later recovery-thereby adding the element of time and introducing an essential skill to the repertoire.

The various reports on large-scale ocean $\mathrm{CO}_{2}$ disposal had emphasized the need for disposal at great depth. Liquid $\mathrm{CO}_{2}$ is highly compressible; it is typically buoyant in seawater but reaches neutral density close to $2,700 \mathrm{~m}$ depth, and will sink to the seafloor when released below that point. It is then very far within the hydrate-forming regime, and the PCAST report optimistically envisaged a "permanent" pile, or lake, of frozen sold hydrate residing safely on the seafloor for a very long time.

In late 1995, MBARI had finally taken delivery of the new R/V Western Flyer that had the potential for multiday trips, and 4,000 m ROV depth capability. Outfitting the ship took considerable time, and few had any real knowledge of the capabilities that were now enabled. We resolved to take advantage of these new assets, and in April 1998 executed a dive to $3,627 \mathrm{~m}$ depth to investigate the liquid $\mathrm{CO}_{2}$ disposal-hydrate formation problem. For this experiment we assembled a 9-liter volume piston accumulator that we filled on deck with liquid $\mathrm{CO}_{2}$ gas; the small gas headspace remaining exerted a pressure of $750 \mathrm{psig}$. This device was carried on the ROV to depth, and the pressure gauges were carefully monitored as we descended. As expected, at about $400 \mathrm{~m}$ depth we observed the $\mathrm{CO}_{2}$ gas-liquid transition take place, and the internal pressure dropped quickly to near zero. Frequent and energetic pumping of the piston was required to maintain pressure (and keep the seawater out) because the highly compressible liquid $\mathrm{CO}_{2} \mathrm{kept}$ losing volume as we dove.

Once at depth, we realized that of the original 9-liter volume we had barely 
4 liters left as our working reservoir. The question was what best to do with it. As classic chemists, we had carried down a 4-liter laboratory beaker, which the pilots carefully set on the seafloor. Into this beaker we carefully dispensed about 1.8 liters of liquid $\mathrm{CO}_{2}$-and to our great relief it did go into the beaker rather than drifting away or instantly plugging the tube with solid hydrate. What happened next took several hours, but it was amazing. We had busied ourselves with other duties for an hour or so, and when we turned our attention back to the beaker, the volume of fluid seemed to have grown. Zooming in with the camera revealed an accumulation of hydrate slush at the bottom of the beaker that was pushing the remaining fluid interface upward.

A few minutes of observation revealed the cause-an "ice storm" on the surface layer was creating crystals of $\mathrm{CO}_{2}$ hydrate that were raining down to the bottom. Soon the volume change was large enough that excess liquid $\mathrm{CO}_{2}$ was overflowing from the beaker, and then rolling along the seafloor with strangely fluidic properties (Figure 1). This happened at least a half dozen times as the complex geochemical "fountain" we had created ran its course.

\section{INVESTIGATING CONSEQUENCES OF OCEAN $\mathrm{CO}_{2}$ DISPOSAL}

Publication of the dramatic $\mathrm{CO}_{2}$ beakerfish image (Figure 1), and the video record of this unusual experiment, quickly attracted worldwide attention. There were two immediate questions: What might be the environmental consequences of pursuing this on a large scale? And, how valid were the assumptions in the PCAST report that at least a semi-permanent form of ocean disposal could be achieved? Both questions could be intuitively answered: (1) adding large quantities of liquid $\mathrm{CO}_{2}$ (say, to form the deep-sea hydrate covered "lake" on the seabed mentioned in the PCAST report) would inevitably create a strong local low pH-high $\mathrm{CO}_{2}$ signal, and (2) given the high solubility of $\mathrm{CO}_{2}$ in seawater, it was very unlikely that any hydrate formed would resist simple dissolution. Yet, these intuitions remained to be tested and clean simple scientific answers were needed.

It is difficult from today's vantage point to grasp the confusion and intensity of views that prevailed at the turn of the twenty-first century. US Vice President Al Gore had endorsed the Kyoto Protocol that essentially promoted reforestation on a very large scale as a climate change

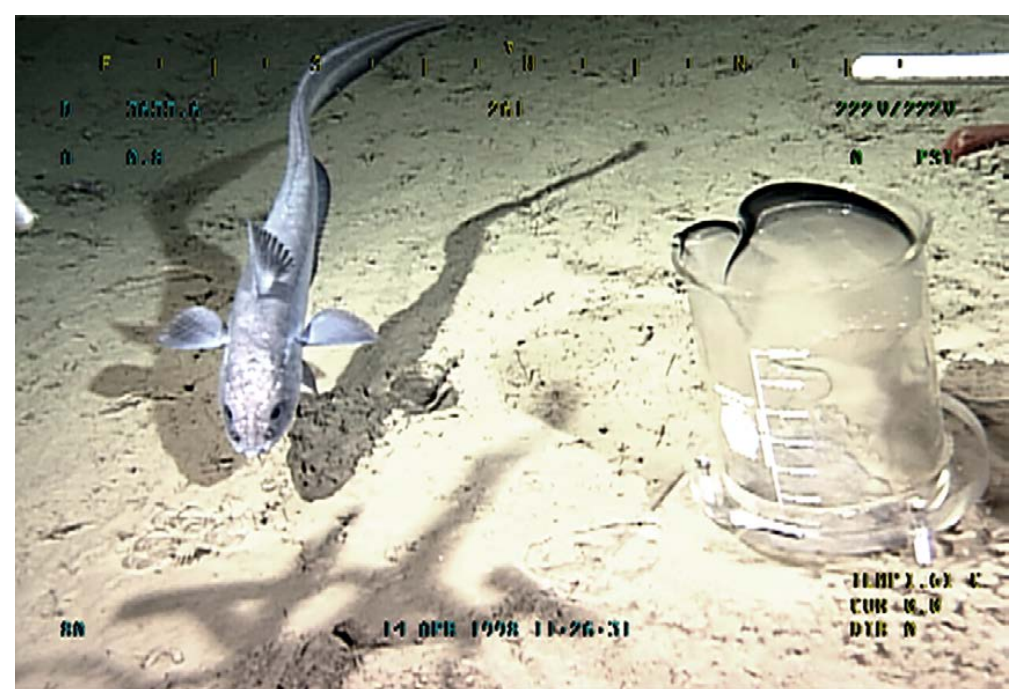

FIGURE 1. A deep-sea $\mathrm{CO}_{2}$ disposal experiment showing overflow of liquid $\mathrm{CO}_{2}$ from a 4-liter beaker placed on the seafloor at 3,627 $\mathrm{m}$ depth. The overflow is caused by rapid formation of a $\mathrm{CO}_{2}$ hydrate $\left(\mathrm{CO}_{2} \cdot 6 \mathrm{H}_{2} \mathrm{O}\right)$ seen as an ice-like slush at the bottom of the beaker. A curious fish inspects the blob of expelled liquid $\mathrm{CO}_{2}$ rolling on the seafloor. From Brewer et al. (1999)

solution. In Norway, a talented team was separating $\mathrm{CO}_{2}$ from a North Sea oil and gas well and re-injecting it into a nearby aquifer. And in Japan, in particular, ocean disposal of $\mathrm{CO}_{2}$ was investigated as a viable option. Climate geoengineering through stratospheric sulfur injection was being reconsidered. There was the distinct appearance that in grappling with the climate challenge, human society had passed through the psychological stages of denial and anger, was then at the bargaining stage-and in transition to acceptance (Brewer, 2007).

\section{The Policy Imperative}

\section{from the IPCC}

The Brewer et al. (1999) publication aroused keen national interest (Brewer, 2000), in particular, within the US Department of Energy. Staff there had been working to find a way to investigate the challenges posed by the PCAST report, and through the international IPCC process, a Special Report on Carbon Dioxide Capture and Storage was being planned; and in 2003 the document was formally authorized. The MBARI experiment crystallized the long latent planning for inclusion of an ocean chapter in this report, which was accomplished (Caldeira et al., 2005). But those charged with writing the chapter were soon faced with lack of actual experimental data.

\section{Executing Experiments in the Deep Sea}

MBARI possessed the near-unique capability, through an independently operated ship/deep ROV system, of executing the deep-sea experiments that were implicit in the planning for the 2005 IPCC report. These deep-sea experiments soon drew in teams from around the world, and colleagues from Norway and Japan were participants (Brewer et al., 2005).

The image of fish close by the "beaker" experiment had aroused significant biological interest, and parallel biological studies were at once planned (Barry et al., 2003, 2004). Yet, this experiment 


\section{Box 1. Personal Reflections}

By Peter G. Brewer

When I first became affiliated with MBARI in September 1990 as the new director, I was quickly instructed into the desires of David Packard for the future direction of the then three-year-old fledgling institute. Clarity of mission was paramount, and there was no question whatsoever as to this: we were to build a unique capability combining equally the talents of engineers and scientists, and centered on deep-sea scientific instrumentation associated with remotely operated vehicles (ROVs). Under no circumstances would we settle for "conventional ocean science." We were to build a new ROV and novel ship with unique scientific capabilities, and use it dominantly within the deep waters of Monterey Bay. We already had a small ship/ ROV system-R/V Point Lobos/ROV Ventana-that operated as a day boat. The new charge was to create "the-mother-ship-for-the-ROV"and this always appeared as one extended word.

The challenge posed by R/V Point Lobos/ROV Ventana was to create a way to quickly have major impact on ocean science while staying within the bounds of Monterey Bay. Point Lobos had no berths and Ventana had limited functionality. Moreover, the laboratory had no significant equipment such as mass spectrometers, and there were no plans to establish this. As I set about building and staffing the physical structure of the institute, and overseeing construction of the new ROV and the SWATH ship as the mother vessel, challenges abounded. One thing seemed clear: if I could not bring deepsea samples to a conventional marine chemistry laboratory (because we didn't have one), then I should use MBARI's ROV to take the chemistry laboratory to the deep sea. This idea was later codified as one of three major engineering priorities set forth in MBARI's 2014 Technology Roadmap-"Taking the laboratory into the ocean."

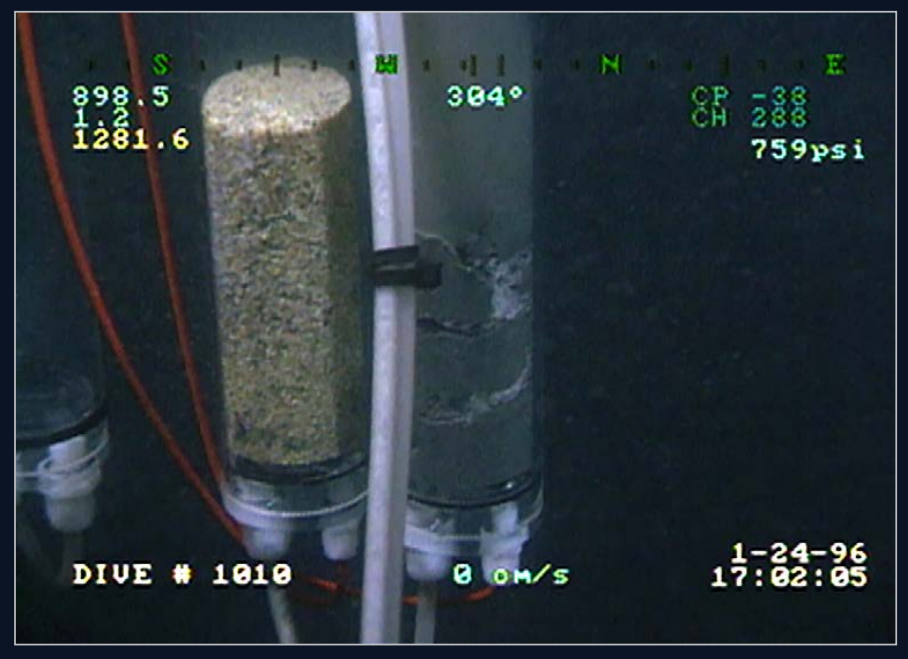

FIGURE B1. The first MBARI effort at deep-sea experimental chemistry (Brewer et al., 1997). In the tube at right, veins of methane hydrates that formed within the flow channels of the fine-grained mud carried from the surface are clearly visible. In the coarse-grained sand that fills the tube at left, a similar but less visible formation soon solidified and fractured. The presence of various forms of errant tubing in the image became an inevitable and ubiquitous feature of this class of deep-sea science.
In those early days there were rumblings of a new national interest in methane hydrates in the deep-sea as a potential energy resource, and corresponding policy documents were being drafted. I became aware of the stark gap between the narratives of laboratory experimentalists and the reports from field geologists; they existed in different worlds. This divide seemed completely unnecessary-the laboratory techniques being used appeared to be readily adaptable to the field. I resolved to break this barrier.

In the fall of 1995, I made plans for a simple in situ experiment carried on the ROV to quickly synthesize methane hydrates in the deep sea. We eagerly read the classic text by Dendy Sloan (Sloan, 1997), who was later to become a wonderful colleague, and we at once recognized that the deep waters of Monterey Bay offered the opportunity to work within the essential high pressure, low temperature phase boundary conditions. There were potential impediments; well-respected papers reported that the formation of methane hydrate required overcoming a large activation energy barrier and that formation was likely to be slow and difficult.

Planning showed we would have at best some three to four hours of experimental time available at depth. Nonetheless, we purchased about $\$ 500$ worth of parts, strapped them onto ROV Ventana, and filled a scuba tank with methane. This contraption was unfamiliar to all. On a bitter cold January morning in 1996, we drove to the center of the Monterey submarine canyon and executed a dive to $910 \mathrm{~m}$ depth $\left(9 \mathrm{MPa}, 4^{\circ} \mathrm{C}\right.$ )-well within the phase boundary for methane hydrate formation. We had installed tubes filled with sand and local mud to simulate sedimentary conditions and provide nucleation sites. The valves were cracked open, and methane gas came bubbling out. There were admittedly some tense moments when hydrates initially failed to appear, and our gas supply was quickly being depleted. But the unmistakable white veins of hydrate did soon form within the sediment columns (Figure B1). The work was quickly published (Brewer et al., 1997) and it established the potential of one dive-one paper.

By this means, we had very simply established a nascent new scientific discipline of executing controlled chemical experiments on the seafloor. In the accompanying article, we document the remarkable growth in experimental skill and understanding of many fundamental principles that was to follow and that has attracted worldwide attention. The majority of this work has been executed with ROVs within the deep waters of Monterey Bay, precisely as David Packard had envisioned a quarter of a century ago. None of this would have been possible without his insistence that MBARI be unlike a traditional academic institution and focus on fostering science/engineering partnerships.

\section{REFERENCES}

Brewer, P.G., F.M. Orr Jr., G. Friederich, K.A. Kvenvolden, D.L. Orange, J. McFarlane, and W. Kirkwood. 1997. Deep-ocean field test of methane hydrate formation from a remotely operated vehicle. Geology 25:407-410, https://doi.org/ 10.1130/0091-7613(1997)025<0407:DOFTOM>2.3.CO;2.

Sloan, E.D. 1997. Clathrate Hydrates of Natural Gases. Marcel Dekker, Inc., New York. 

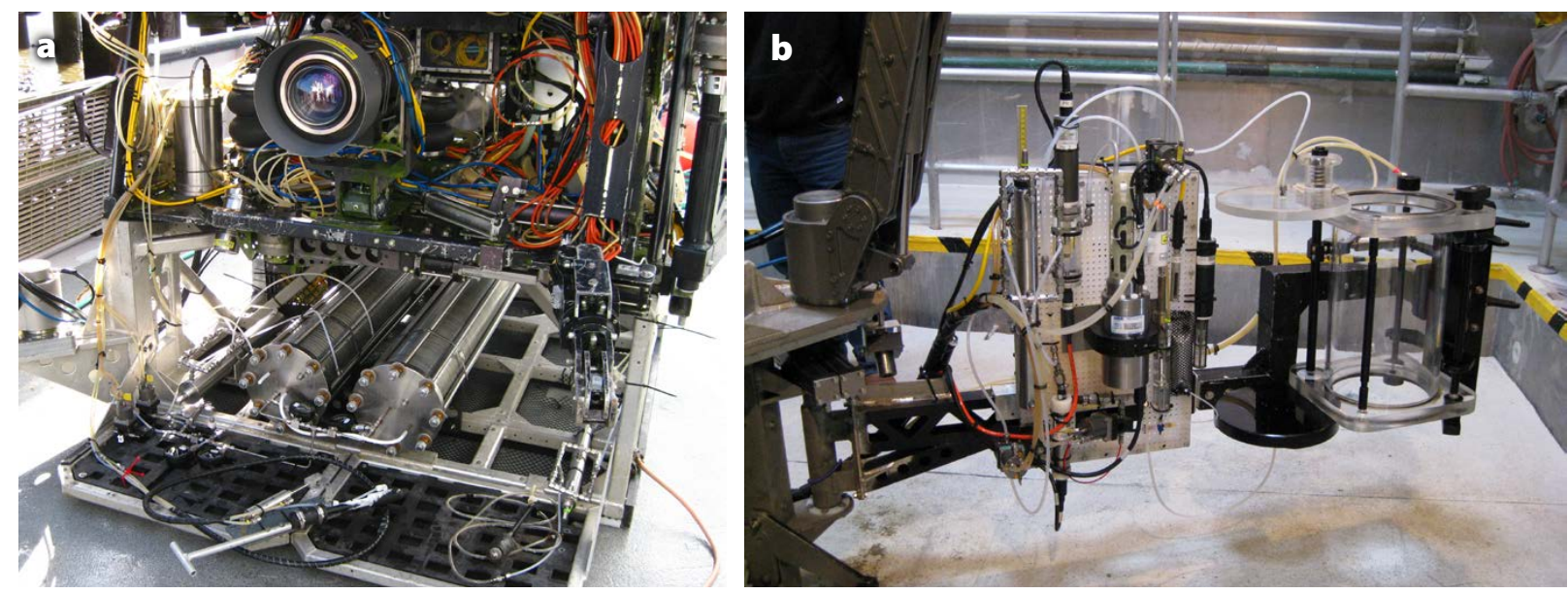

FIGURE 2. (a) Two 56-liter carbon fiber piston cylinders on the ROV were used to deliver liquid $\mathrm{CO}_{2}$ at depth. The high compressibility of the fluid resulted in only $\sim 40$ liters at 3,000 m depth per cylinder. (b) A pH measurement assembly was arranged so that a tube could be inserted by the vehicle arm into critical locations and the fluid pulled through the measurement cell.
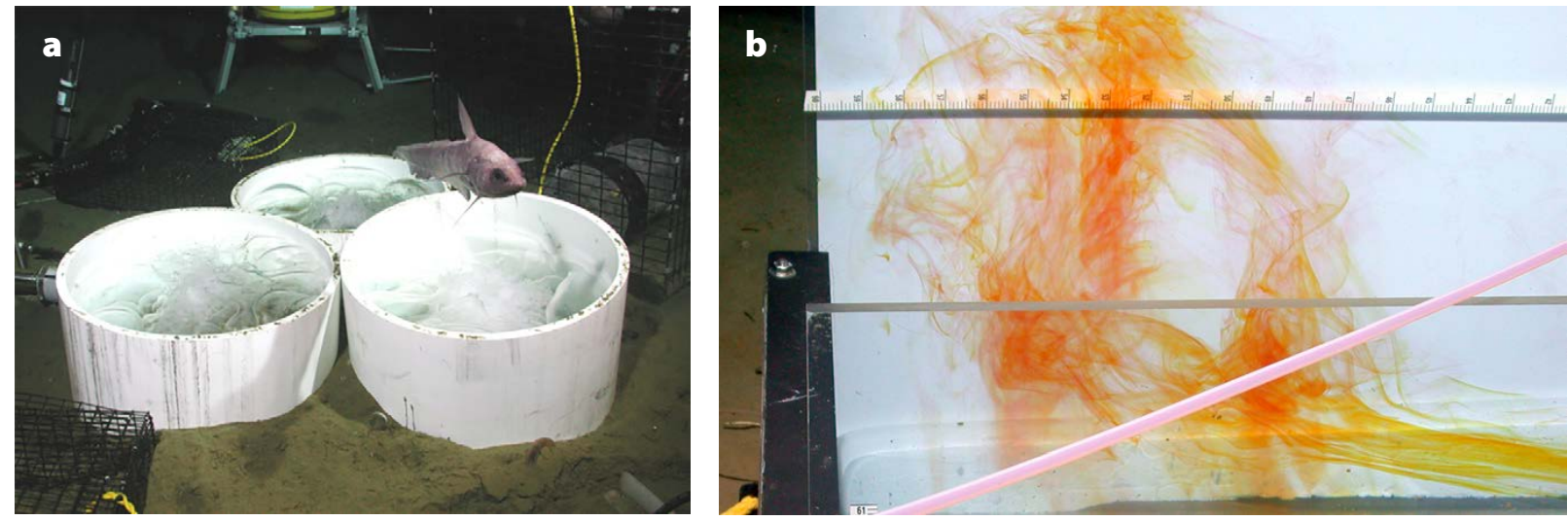

FIGURE 3. Apparatus for deep-sea experiments on the behavior and environmental impact of pools of liquid $\mathrm{CO}_{2}$ on the deep-sea floor. The density of liquid $\mathrm{CO}_{2}$ is greater than that of seawater at $>3,000 \mathrm{~m}$ depth. (a) Three corrals of liquid $\mathrm{CO}_{2} \mathrm{Covered}$ with a thin film of hydrate attracts the interest of a deep-sea fish. (b) A flume containing liquid $\mathrm{CO}_{2}$ with active flow across the surface. Injection of $\mathrm{pH}$-sensitive dye has created a yellow-orange color plume. From Brewer et al. (2005)

required far larger quantities of $\mathrm{CO}_{2}$ as well as development of associated $\mathrm{pH}$ measurement protocols unavailable on the first dive (Figures 2 and 3 ).

\section{Experiments in the Ocean Water Column}

Experiments at depths $>3,000 \mathrm{~m}$ such as these enabled creation of a gravitationally stable fluid that could be manipulated. It was less obvious how such a deep injection could be achieved on a practical scale. Cartoon sketches circulated at the time visualized a ship with a pipe extending to the mid-water region, and from this a sinking flow would emerge (Hanisch, 1998). How this flow would be achieved was unknown, but there were fanciful ideas. It was recognized that solid $\mathrm{CO}_{2}$ hydrate was more dense than the pure liquid form, and so limited was the understanding that at one point it was hypothesized that a rising droplet of liquid $\mathrm{CO}_{2}$ released into the ocean would steadily accrete a hydrate skin, causing it to slow its ascent and then sink to great depth (Holder et al., 1995).

It was clear at this point that simple and direct experiments to shed light on how deep injection might work were required. In order to investigate the fate of individual droplets, a "bubble box" was created (Brewer et al., 2002; Rehder et al., 2002) and carried on the MBARI ROV for direct imaging of ascending droplets and bubbles (Figure 4b). These data revealed that the dissolution rate of the liquid $\mathrm{CO}_{2}$ droplet was $3.0 \mu \mathrm{mol} \mathrm{cm} \mathrm{cm}^{-2} \mathrm{~s}^{-1}$, with the rise rate proportional to droplet size.

In later work (Tsouris et al., 2004, 2007), we showed that a sinking slug of $\mathrm{CO}_{2}$ hydrate could indeed be formed in the water column (Figure 4b, but only via a carefully designed injector that forced liquid $\mathrm{CO}_{2}$ and water together in a jetted reaction tube. Yet, these solid phases too quickly dissolved on sinking into the undersaturated ocean water column, as was also shown by direct observation of the dissolution of carefully synthesized solid pellets of both $\mathrm{CH}_{4}$ and $\mathrm{CO}_{2}$ hydrates emplaced on the seafloor (Rehder et al., 2004). 


\section{Stimulating Ocean}

\section{Acidification Science}

The 2005 IPCC report served to highlight a number of technical problems: first, the high cost of $\mathrm{CO}_{2}$ capture from combustion gases; next, the high cost of pipelines to transport the liquid $\mathrm{CO}_{2}$; and finally, the challenge of injecting large quantities of liquid $\mathrm{CO}_{2}$ at great ocean depth. The effect of creation of a large plume of $\mathrm{CO}_{2}$ richlow $\mathrm{pH}$ seawater was acknowledged, but importantly there was no consensus as to how harmful to marine life that might be.

Within the United States, and within the Scientific Committee on Oceanic Research (SCOR), there was considerable interest in this topic. Drafts of the IPCC report had circulated, and the matters raised had to be evaluated. SCOR staff had received NSF support to hold an international meeting on the likely consequences, and a November 2003 meeting was convened at the National Academy of Sciences Beckman Center to make plans. Author Peter Brewer attended that meeting and pointed out the simple arithmetic: ocean "disposal" of $\mathrm{CO}_{2}$ from the atmospheric invasion was now approaching 1 million tons of $\mathrm{CO}_{2}$ per day-and disposal of even $1 \%$ of this $\mathrm{CO}_{2}(10,000$ tons per day) would be almost impossible to achieve by direct industrial injection. If there were to be environmental threats from adding large quantities of $\mathrm{CO}_{2}$ to the ocean, then the danger was the real "free" invasion from the sky, not the hypothetical and expensive disposal from a pipe (Brewer, 2004). The ocean was acidifying anyway (Brewer, 1997).

From this meeting, plans for holding the first High $\mathrm{CO}_{2}$ Ocean workshop in Paris in May 2004 were quickly laid, and that event (Cicerone et al., 2004) nearly single-handedly triggered the widespread interest in ocean acidification that continues today (Gattuso and Hansson, 2011).

\section{NEW INSTRUMENTATION FOR DEEP-OCEAN RESEARCH}

The mandate from David Packard was for MBARI "to develop better instruments, systems, and methods, for scientific
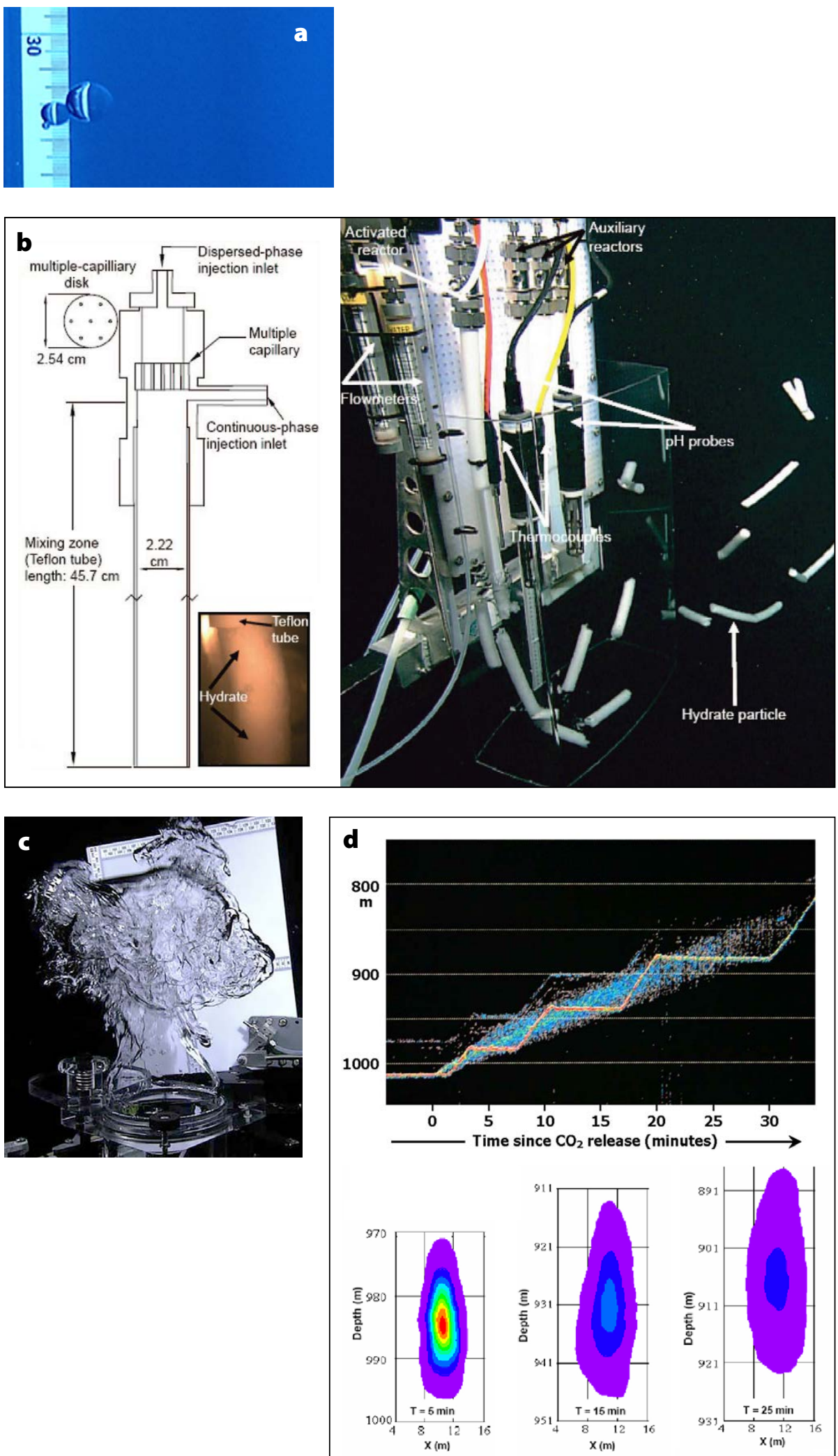

$\begin{array}{lllll}128 & 251 & 374 & 497 & 620\end{array}$

Droplet number $/ \mathrm{m}$

FIGURE 4. (a) Image of an ascending droplet of liquid $\mathrm{CO}_{2}$, released at $800 \mathrm{~m}$ depth and tracked in real time over 300 m of ascent. From Brewer et al. (2004) (b) Image of extrusion of toothpaste-like $\mathrm{CO}_{2}$ hydrate slugs formed within an injector reactor system between 1,000 $\mathrm{m}$ and 2,000 $\mathrm{m}$ depth. From Tsouris et al., (2007) (c) A sudden release of 5 liters of liquid $\mathrm{CO}_{2}$ into the water column at $1,000 \mathrm{~m}$ depth, and (d) the two images plot acoustic tracking of its plume from shipboard sonar and from ROV-carried sonar (From Brewer et al., 2006) 
research in the deep waters of the ocean." The work described above fell into the category of "systems and methods"-but the development of better instruments remained to be tackled. Moreover, given the insistence on using ROV platforms as the prime vehicle for deep-sea deployment of an ROV-based, controlled, and operated instrument yielding real-time data was a clear goal.

Our participation in the planning and execution of the experiments described above had given our team a very clear idea of what instruments might be compatible with the specific $\mathrm{ROV}$ requirements and essential pilot skills available to us. It was clear that laser-based systems were well suited-a parallel pair of lasers for target size estimation was in routine use, and all data were transmitted from vehicle to ship via single-mode optical fibers. Lasers were also a ubiquitous part of modern chemistry-as practiced in the academic world, though rarely at sea. There was plainly a gap to be filled, and recent developments in laser Raman spectroscopy caught our eye.

Raman spectroscopy involves the molecular scattering of light by polarizable bonds, with a resulting and predictable frequency shift. It is a notoriously weak signal with only $\sim 1$ in $10^{8}$ photons returned, but the information gained is related to fundamental rules of chemical physics (Brewer and Kirkwood, 2013). Remarkably, the opening section of Raman's Nobel Prize Lecture (Raman, 1930) is entitled "The colour of the sea" where on a voyage he noted "...the wonderful blue opalescence of the Mediterranean Sea. It seemed not unlikely that the phenomenon owed its origin to the scattering of sunlight by the molecules of the water." In this matter, it is likely that Raman was misled, for the effect is more likely arising from chlorophyll fluorescence, and modern studies of Raman spectroscopy of water in seawater (Brewer et al., 2017) would be impossible with any opalescence from the water molecules themselves.

Ocean geochemists have been remark- ably neglectful of the adaptation of modern laser techniques for in situ measurement and when a deep-ocean laser Raman system was first proposed, there was very considerable skepticism: "The fluorescence will kill the signal." "It can't measure oxygen, $\mathrm{CO}_{2}$ and nutrient so what good is it?" "It's non-quantitative." "It's way too fragile."

Yet, there were hints of opportunity. Laboratory work at the Colorado School of Mines (Sum et al., 1997) showed that methane hydrate structure and composition could be measured via Raman techniques. A survey of similar instruments suggested that it would be possible, but potentially risky, to package a unit in a deep-sea pressure housing and return real-time data via MBARI's ROV. We proposed to take the risk.

The challenge appeared formidable. Manufacturers were skeptical, for these laboratory instruments were seen as fragile, with components loosely hooked together with cabling. Nonetheless, a collection of components was purchased (Kaiser Optical), packaged, and connected to MBARI's ROV Ventana (Brewer et al., 2004; Pasteris et al., 2004). The early experiments revealed both promise and challenge. The challenges were posed by the cumbersome system requiring three separate pressure housings, and unfamiliar geochemical signals. The promise lay in the fact that novel gas, liquid, and solid phases could be observed in remarkable detail, for example, direct in situ differentiation of calcite and aragonite phases, and separation of the dissolved, gaseous, and hydrate forms of methane.

\section{DEVELOPING QUANTITATIVE RAMAN TECHNIQUES}

Ocean scientists demand quantitative data, and the widespread idea that Raman results fell short of this standard was disturbing and had to be solved. Dunk et al. (2005) tackled this problem. We were interested in creating deep-sea controlled $\mathrm{CO}_{2}$ enrichment experiments for investigating ocean acidification impacts on deep-sea marine life. For this experiment, we sought a way to create a $\mathrm{CO}_{2}$-rich seawater working fluid, milked from a liquid $\mathrm{CO}_{2}$ source, to be metered into experimental chambers-not an easy task.

We devised an experiment $(500 \mathrm{~m}$ depth, $6^{\circ} \mathrm{C}$ ) using ROV Ventana in which a stream of seawater was slowly pumped across a liquid $\mathrm{CO}_{2}$ surface and the $\mathrm{pH}$ of the enriched water flow carefully observed. We also installed the laser Raman probe head in the same fluid stream and made parallel measurements. The results (Figure 5) clearly showed that by normalizing the Raman peaks to the ubiquitous and unvarying water $v 2$ bending mode band (the concentration of water in seawater is $\sim 55 \mathrm{M}$ ), fully accurate measurements could be made. Today, the advances that have been made permit deep ocean measurement accuracy of $\pm 1 \%$, even of species embedded in a complex thicket of competing bands.

This technique was later used to great effect and on a large scale in executing a deep-sea cabled observatory ocean acidification experiment (Barry et al., 2014; Kirkwood et al., 2014).

\section{Observing the Seafloor}

The tragic April 2010 Deepwater Horizon massive oil spill in the Gulf of Mexico greatly stimulated interest in the hydrocarbon status of the seafloor. In practice, ocean geochemists had long been aware of the deficiencies in observing methane in sediment pore waters (Paull and Ussler, 2001). The evidence showed that even in locations known to have high dissolved methane, the pore waters of recovered cores all clustered around the same number-the one atmosphere saturation value.

There was, of course, a long and well-respected history of pore water measurements, with careful reviews by Burdige (2007) on sediment organic matter preservation, and by Reeburgh (2007) on methane geochemistry. But all previous studies had to rely upon analysis of recovered samples, and the authors were keenly aware of the drawbacks.

The solution was clearly to make the 
a

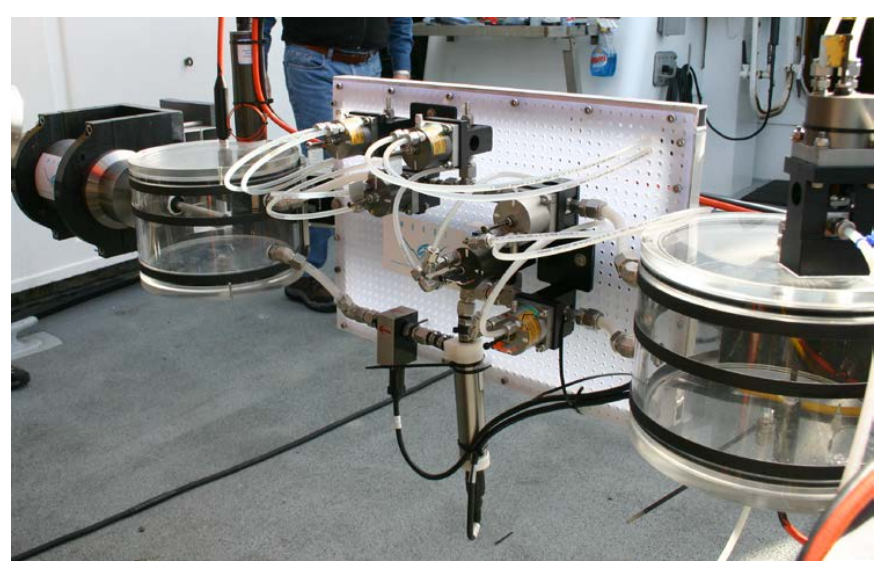

\section{c}

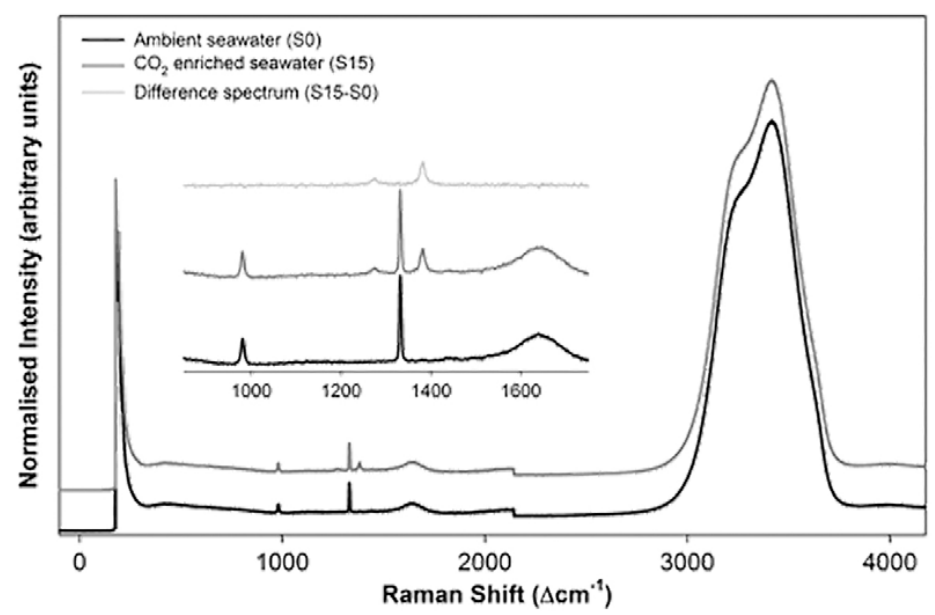

b
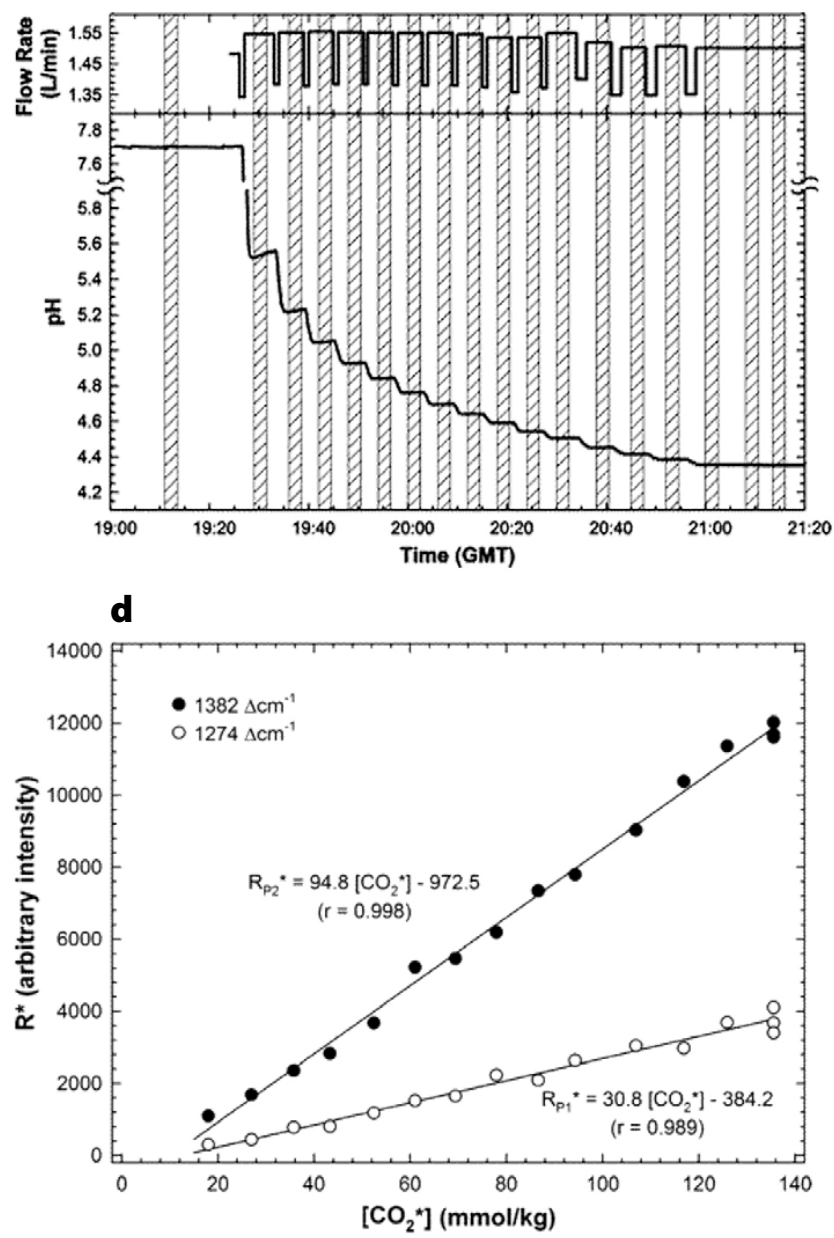

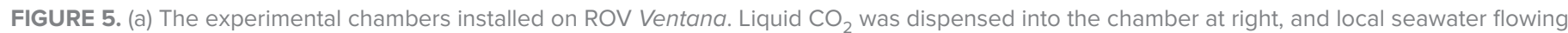

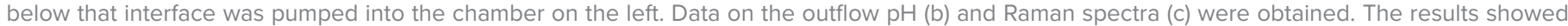

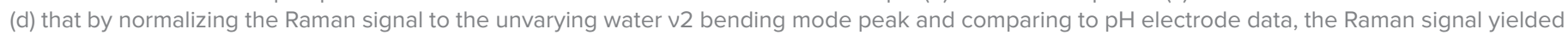
an accurate analysis of the dissolved $\mathrm{CO}_{2}$. From Dunk et al. (2005)

analyses in situ, but no practical way to do so was known. Zhang et al. (2010) presented the first results from a newly designed pore water probe attached to the Raman system (Figure 6). Once the probe was inserted by the ROV robotic arm into the sediments, pore water was pulled through a metallic frit into a small optical cell fitted with a sapphire window through which the laser beam was focused and pore water spectra obtained in real time.

This system was first tested in Monterey Bay where the dissolved sulfate and sulfide signals were observed. But the most important applications were found in association with the massive methane hydrate-rich systems well to the north and to the south (Zhang et al., 2011). Here, it was clearly shown (Figure 7a) that whereas the in situ Raman data showed the elegant and orderly equivalence of declining concentration of sulfate ion being perfectly matched by the rising

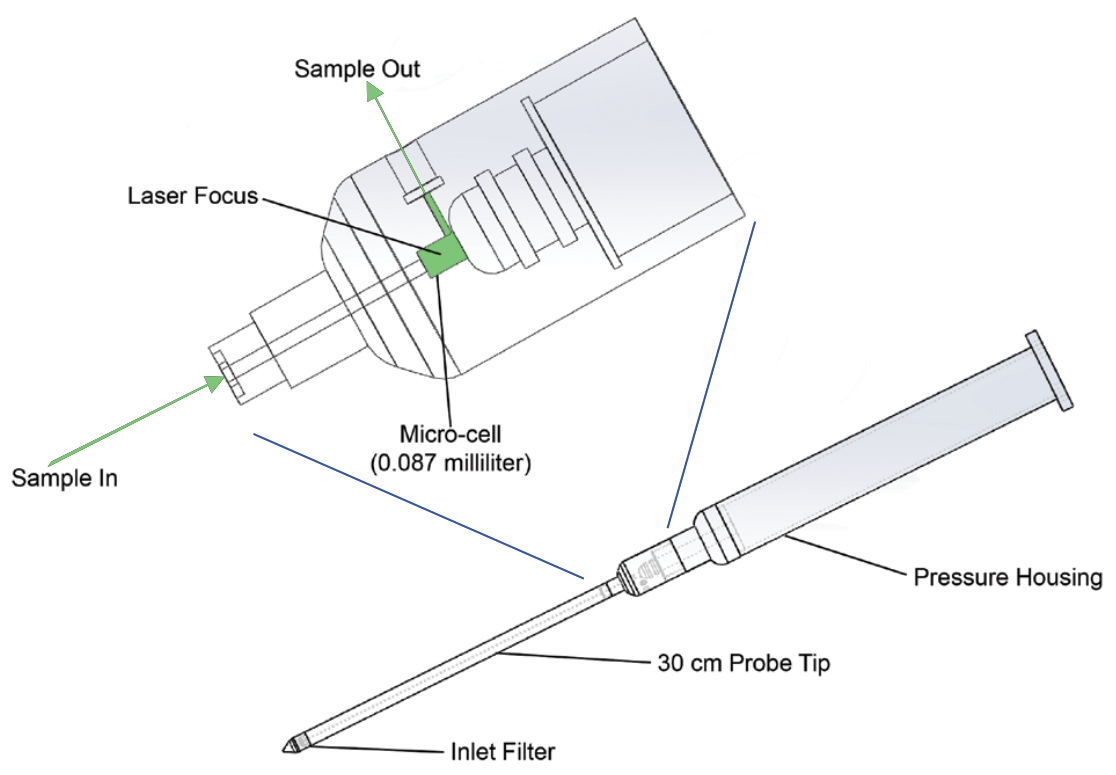

FIGURE 6. Engineering drawing of the Raman pore water probe unit showing the optical microcell detail. From Zhang et al. (2010) 

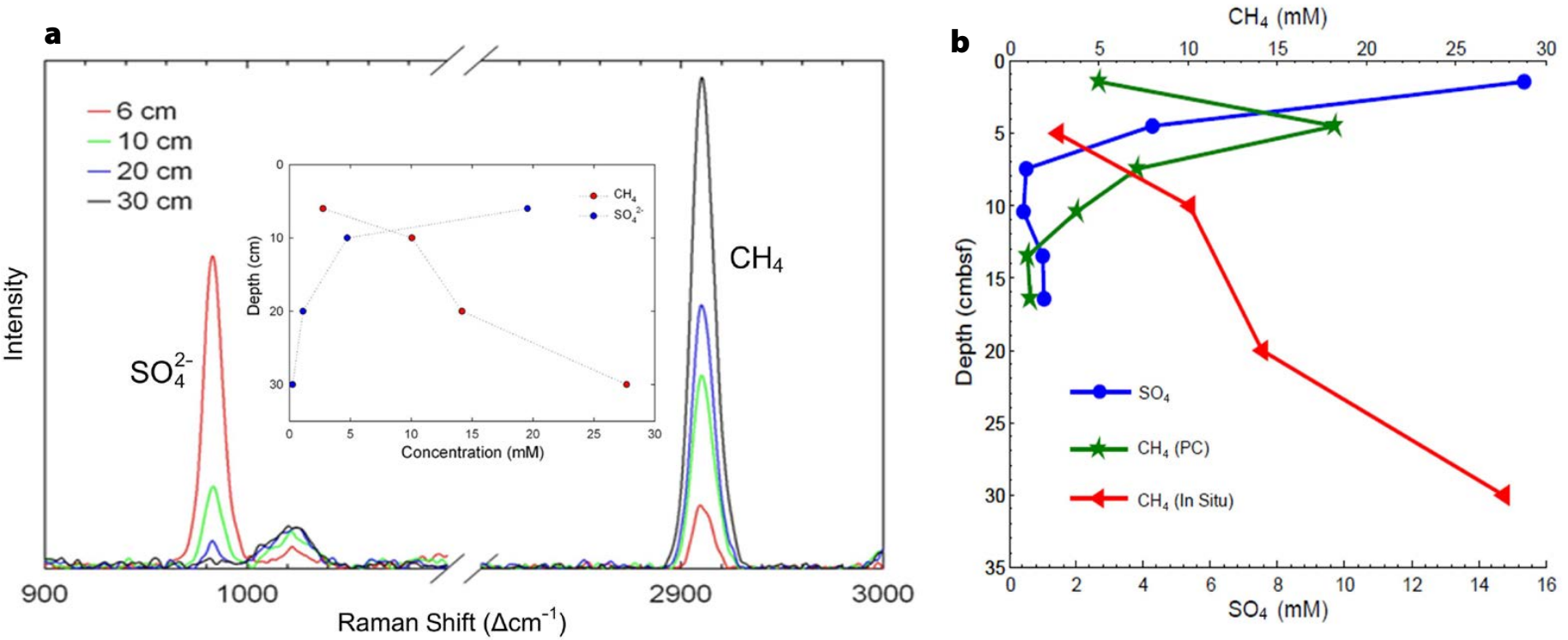

FIGURE 7. (a) Compilation of Raman spectra obtained from step-wise probe insertion at a single station at Hydrate Ridge, offshore Oregon; other sites sampled showed identical trends. The $\mathrm{SO}_{4}^{2-}$ peak at $981 \Delta \mathrm{cm}^{-1}$ rapidly declines from its seawater value of $28.9 \mathrm{mM}$ to vanishingly small levels. In a mirror image of this trend, dissolved $\mathrm{CH}_{4}$ with a Raman shift of 2,910 $\Delta \mathrm{cm}^{-1}$ rises strongly from nanomolar concentrations in deep-sea water to about $28 \mathrm{mM}$ at $30 \mathrm{~cm}$ depth. (b) Equivalent results from recovered push cores showing the discrepancy between in situ (red line) and recovered cores (green line). From Zhang et al. (2011)

concentration of methane, the recovered cores (Figure 7b) showed some $30 \times$ less dissolved methane. This was proof positive of massive degassing of dissolved methane during core recovery.

Most ocean geochemists are familiar with the frequent stench of sulfide gas from recovered cores. The smell alone is testimony to significant degassing and signal loss. Here, too, the spectral data obtained at depth provide not only accurate information but also permit the detection of both the $\mathrm{H}_{2} \mathrm{~S}$ and $\mathrm{HS}^{-}$ forms-and from their ratio an accurate measure of in situ pH (Peltzer et al., 2016).

\section{Testing Fossil Fuel Energy Policy}

One of the earliest drivers for a national program on methane hydrates was the possibility of direct energy recovery from producing the frozen methane. Although large outcrops of near-pure methane hydrate can be found exposed on the seafloor, the vastly greater amount is contained in the pores of geologic formations, particularly in the Arctic (Kleinberg and Brewer, 2001; NRC, 2004). The methods for detection of hydrates within pore spaces were not well developed, and basic understanding was lacking. In order to resolve this dilemma, we initiated a bold experiment in collaboration with colleagues from Schlumberger and asked whether it could be possible to couple their impressive well-logging nuclear magnetic resonance (NMR) instrument with MBARI's ROV. An agreement was reached, and with some difficulty, the 18-foot-long (5.5-meter-long), $2 \mathrm{MHz}$ Schlumberger NMR instrument (Kleinberg, 1996) was converted to an L shape and installed on ROV Tiburon. This was challenging in the extreme: the magnetic fields affected vehicle navigation, and the instrument that had hitherto been exposed only to hot downhole conditions had to be adjusted to work in the cold deep ocean. The at-sea experiments proved difficult, but we were successful in creating methane hydrate within the pore spaces of sandstone cores, and detecting the change from the normal liquid-filled state in a quantitative manner (Kleinberg et al., 2003). The outcome was a much-improved ability to explore the hydrate status of a now-warming Arctic.

The long sequence of experiments above initiated in 1997 by energy policy and environmental concerns reached its conclusion with the testing of a bold idea. It had long been debated that, because $\mathrm{CO}_{2}$ hydrate was thermodynamically more stable than $\mathrm{CH}_{4}$ hydrate, it might be possible to accomplish two goals simultaneously, that is, to dispose of captured fossil fuel $\mathrm{CO}_{2}$ into a geologic hydrate reservoir where it would spontaneously "steal" the enclathrated water, form a more stable solid $\mathrm{CO}_{2}$ hydrate, and release free $\mathrm{CH}_{4}$ gas as a usable energy resource. This optimistic "eat your cake and have it too" hypothesis had obvious attractions, and numerous laboratory pressure cell experiments had raised hopes (Lee et al., 2003; Park et al., 2006; Ota et al., 2007). Based on this, a very large ( $\sim 20 \mathrm{M})$ US Department of Energy-sponsored field project was initiated at an Arctic site in 2012 (see http://www.netl.doe.gov/ research/oil-and-gas/methane-hydrates/ co2_ch4exchange).

Our experience with hydrate geochemistry in the deep ocean suggested that useful insights might be gained with a simple local ROV experiment that straddled the gap between closed pressure cell microsystems and the large industrialscale drilling project.

In alliance with colleagues from the US Geological Survey, we emplaced carefully synthesized rods of solid $\mathrm{CH}_{4}$ hydrate in a pressure vessel for transport to the Monterey Bay seafloor at $690 \mathrm{~m}$ depth. There, with astonishing skill in pilot handling of the experiment, the 
hydrate specimens were introduced into a large glass cylinder full of a $\mathrm{CO}_{2}-\mathrm{N}_{2}$ gas mixture, thus mimicking the laboratory pressure cell study reported by Park et al. (2006). Progress of the experiment was then monitored in real time with the Raman laser (Figure 8).

The results of the experiment clearly showed that the proposed scheme would not work. Enthusiasts had not noted that the high solubility of $\mathrm{CO}_{2}$ gas into the formation water would continuously deplete the gas phase. The resulting gas mixture, steadily enriched in $\mathrm{N}_{2}$, would indeed force dissociation of the methane hydrate. But, instead of liberating a pure $\mathrm{CH}_{4}$ gas phase, only a $\mathrm{N}_{2}-\mathrm{CH}_{4}$ gas mixture of limited value would result. This experiment executed by a small team took only two days of ship-ROV time-a remarkable tribute to efficiency.

\section{LOOKING TO THE FUTURE}

All of the above experiments were executed exactly as envisioned by David Packard-using ROV-enabled techniques within the deep waters of Monterey Bay to provide clear and simple answers to important unanswered questions. The experiments required remarkable discipline derived from classic engineering principles-very specific goals and procedures had to be identified and then executed at depth within a typical fivehour time window.

Those same attributes can be applied more widely, and examples can be found in investigating climate change impacts on oceanic ecosystems. Climate change problems can appear so diffuse and long term that identifying specific impacts can be challenging. But again, quantitatively examining local phenomena in simple chemical engineering terms can provide fundamental clues to largerscale processes.

\section{An Ocean Warming/Oxygen \\ Tipping Point Evaluated}

The oxygen minimum zone within Monterey Bay occurs at about $650 \mathrm{~m}$ depth and is poised at about $12 \mu \mathrm{mol} \mathrm{O}_{2} \mathrm{~kg}^{-1}$. It is close to the equivalence point $(\sim 10 \mu \mathrm{mol})$ at which microbes also begin to use $\mathrm{NO}_{3}$ ions in parallel with $\mathrm{O}_{2}$, and it is highly stressful to aerobic marine life. Because ocean warming of only $2^{\circ} \mathrm{C}$ will reduce $\mathrm{O}_{2}$ solubility by $14 \mu \mathrm{mol} \mathrm{O}{ }_{2} \mathrm{~kg}^{-1}$, then clearly near-complete local loss of dissolved oxygen could occur. But the rules governing this $\mathrm{O}_{2}-\mathrm{NO}_{3}$ balance were based largely on 50-year-old observational lore-could they be codified in chemical engineering terms? In 2014, we were able to solve this problem (Brewer et al., 2014a) in terms of the rate of availability of the electron acceptor simply by inverting the classical equations. Figure 9 shows the result of this calculation: the formal calculation of the rate of availability of chemical energy in $\mathrm{pJ} \mathrm{s}^{-1}$ from either an $\mathrm{O}_{2}$ or an $\mathrm{NO}_{3}$ source precisely matches the old established "rule of thumb" approach. And from this result, the oxidizing potential of the $\mathrm{NO}_{3}$ ion provides only a modest buffer against a true dead zone appearing in Monterey Bay under ocean warming.

\section{The Effects of Changing \\ Temperature on Marine \\ Ecosystems}

Ocean oxygen levels in the shallow water masses of Monterey Bay are declining, almost certainly due to warming and increased stratification. Strange to say, a great many scientific papers on climaterelated phenomena have traditionally avoided the direct explication of temperature effects; instead, biogeochemical rates have almost invariably been reported as functions of depth (Brewer and Peltzer, 2016). There are historical reasons for this reporting. Over 50 years ago when the first estimates of oxygen consumption rates in the ocean were made, it was realized that the controls might be related to amount of organic matter, or temperature, or depth, or other factors-but because most of these properties scaled in proportion to

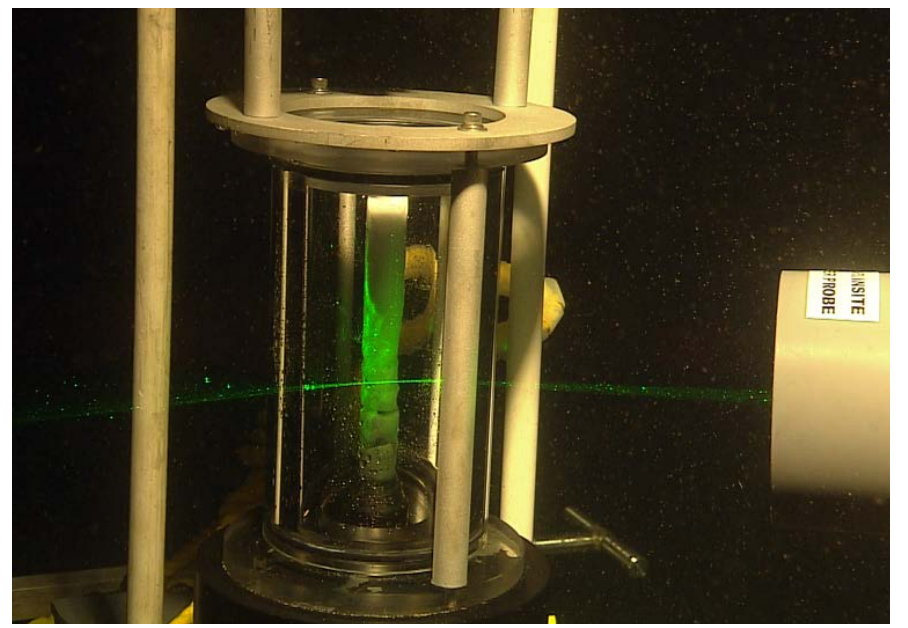

FIGURE 8. Image of the Raman laser at 690 m ocean depth interrogating a rod of methane hydrate bathed within a gaseous $\mathrm{CO}_{2}-\mathrm{N}_{2}$ mixture. From Brewer et al. (2014b)

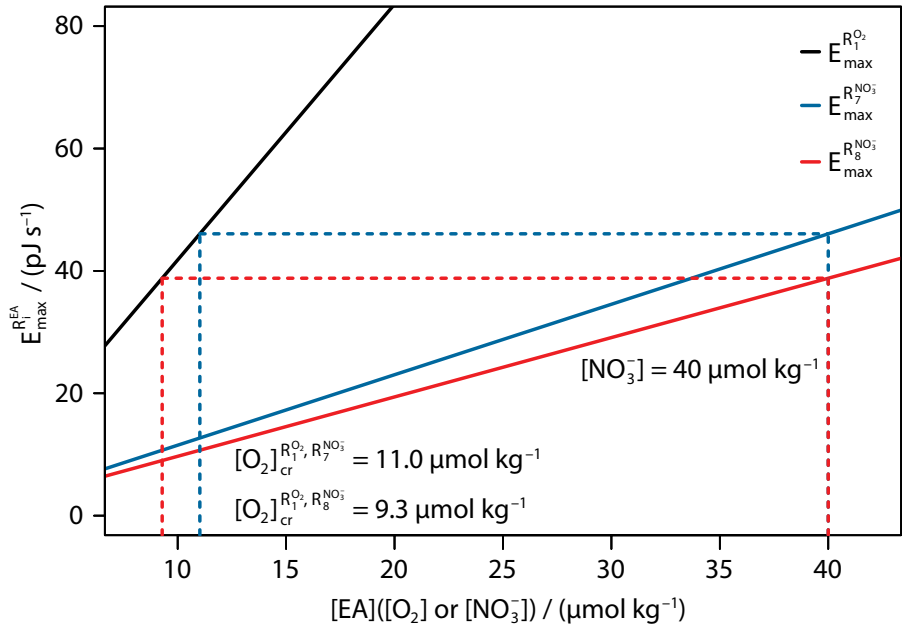

FIGURE 9. Comparative graph of the rate (y-axis) at which microbes can gain energy from marine organic matter using the concentration (x-axis) of either $\mathrm{O}_{2}$ or $\mathrm{NO}_{3}$ as an electron acceptor. The equivalence point is when the ratio is close to $4: 1$. The ocean $\mathrm{NO}_{3}$ buffer against oxygen loss is small. From Brewer et al. (2014a) 
depth, writing things out this way was a seemingly easy fix. So, a tradition of writing out ocean chemical rates as a function of depth was born-and continued unaltered for over half a century.

Yet, there are clearly better ways to tackle this problem. Over the years, the ability to estimate ocean oxygen consumption rates has improved enormously (Stanley et al., 2012; Sonnerup et al., 2013) so that more rigorous tests of the underlying molecular basis can be applied. In a recent paper, Brewer and Peltzer (2017) show that a worldwide compilation of ocean oxygen consumption rate data can be well represented by classical Arrhenius and Eyring functions with a solid chemical physics basis (Figure 10).

Viewed in this light, the vast ocean oxygen field can be seen as a tracer of the microbial consumption of organic matter-the food supply for deep-sea life. The changing pattern of ocean oxygen loss under climate change is revealing. As climate warming occurs, microbes are more quickly consuming the chemical energy raining down from the sea surface and at ever-shallower depths. Thus, even where there is an abundant supply of dissolved oxygen, the rich high-latitude benthic ecosystems will be challenged by a marked reduction in their food supply as the microbes increase their share.

\section{CONCLUSIONS}

This article is written as homage to MBARI's founder David Packard. His instinct that engineering discipline applied to ocean science problems would yield novel advances has been inspiring. He was convinced that many fundamental problems could be solved by careful work within the deep water of Monterey Bayfar-flung expeditions should be only a last resort. To a great degree, the progress reviewed here has borne this out. In doing so, we may recall the pithy comment by Voltaire to his friend La Condamine on the travels and travails required on the expedition to observe the obliquity of the

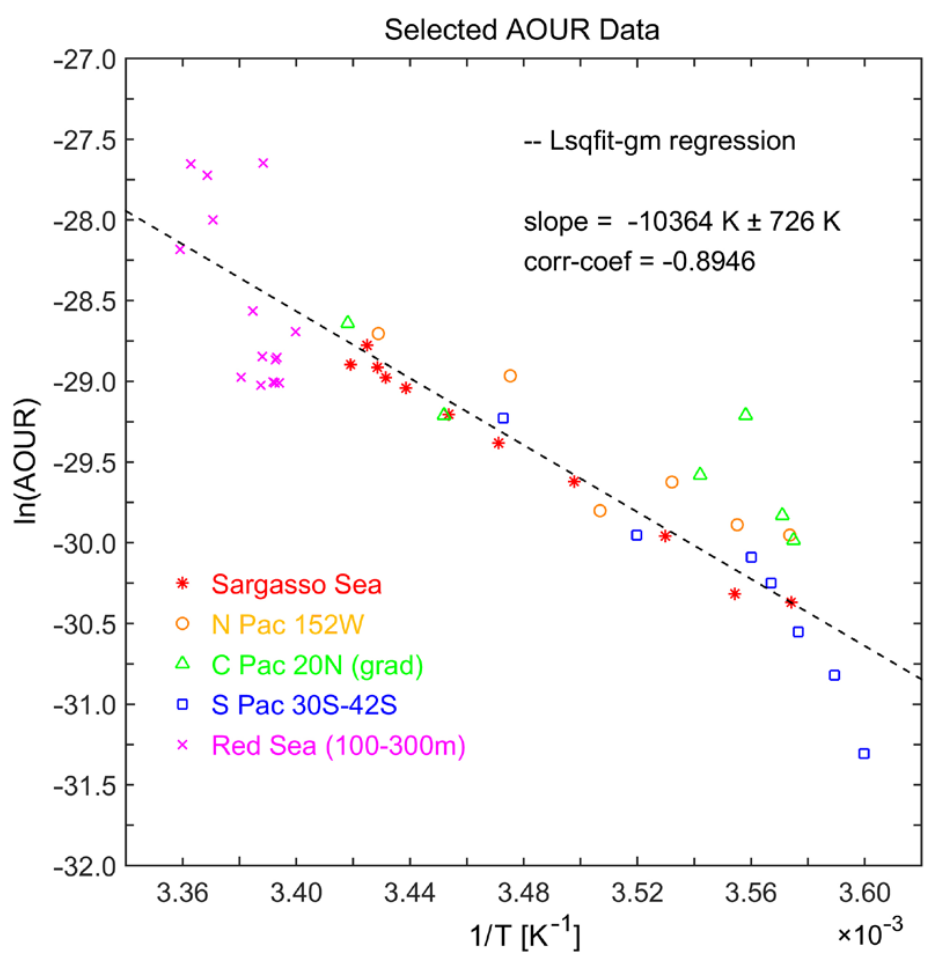

FIGURE 10. Apparent ocean oxygen consumption rate (AOUR) data plotted as an Arrhenius function, showing a worldwide consistency with an activation energy of $86.3 \mathrm{~kJ} \mathrm{~mol}^{-1}$. From these data, we derive a $\mathrm{Q}_{10}$ of 3.63 . Thus, under $2^{\circ} \mathrm{C}$ warming, the consumption rate of marine organic matter will increase by $29 \%$, for $3^{\circ} \mathrm{C}$ warming by $50 \%$. These increases will have profound consequences for marine ecosystems. From Brewer and Peltzer (2017)
Earth: Vous avez trouve par de long ennuis ce que Newton trouva sans sortir de chez lui. (You have discovered through a long boring journey that which Newton found without leaving home.)

Not all ocean science problems can be tackled chez lui-but Dave's intuition was that an important select group of problems can. @

\section{REFERENCES}

Barry, J.P., B.A. Seibel, J.C. Drazen, M.N. Tamburri, K.R. Buck, C. Lovera, L. Kuhnz, E.T. Peltzer, K. Osborn, P.J. Whaling, and others. 2003. Deepsea field experiments on the biological impacts of direct deep-sea $\mathrm{CO}_{2}$ injection. In Proceedings of the Second Annual Conference on Carbon Sequestration. US Department of Energy.

Barry, J.P., K.R. Buck, C.F. Lovera, L. Kuhnz, P.J. Whaling, E.T. Peltzer, P. Walz, and P.G. Brewer 2004. Effects of direct ocean $\mathrm{CO}_{2}$ injection on deep-sea meiofauna. Journal of Oceanography 60:759-766, https://doi.org/ 10.1007/s10872-004-5768-8.

Barry, J.P., C. Lovera, K.R. Buck, E.T. Peltzer, J.R. Taylor, P.M. Walz, P.J. Whaling, and P.G. Brewer. 2014. Use of a free ocean $\mathrm{CO}_{2}$ enrichment (FOCE) system to evaluate the effects of ocean acidification on the foraging behavior of a deep-sea urchin. Environmental Science \& Technology 48(16):9,890-9,897, https://doi.org/ 10.1021/es501603r.

Brewer, P.G. 1978. Direct observation of the oceanic $\mathrm{CO}_{2}$ increase. Geophysical Research Letters 5:997-1,000, https://doi.org/10.1029/ GL005i012p00997.

Brewer, P.G. 1997. Ocean chemistry of the fossil fuel $\mathrm{CO}_{2}$ signal: The haline signature of "business as usual." Geophysical Research Letters 24:1,367-1,369, https://doi.org/10.1029/ 97GL01179.

Brewer, P.G. 2000. Contemplating action: Storing carbon dioxide in the ocean. Oceanography 13(2):84-92, https://doi.org/ 10.5670/oceanog.2000.38.

Brewer, P.G. 2004. Direct injection of $\mathrm{CO}_{2}$ in the ocean. Pp. 469-478 in Toward $\mathrm{CO}_{2}$ Stabilization: Issues, Strategies, and Consequences. C. Field and M.R. Raupach, eds, Island Press.

Brewer, P.G. 2007. Evaluating a technological fix for climate. Proceedings of the National Academy of Sciences of the United States of America 104:9,915-9,916, https://doi.org/10.1073/ pnas.0703892104.

Brewer, P.G., B. Chen, R. Warzinski, A. Baggeroer, E.T. Peltzer, R.M. Dunk, and P. Walz. 2006. Threedimensional acoustic monitoring and modeling of a deep-sea $\mathrm{CO}_{2}$ droplet cloud. Geophysical Research Letters 33, L23607, https://doi.org/ 10.1029/2006 GL027181 10.1029/2006GL027181.

Brewer, P.G., G. Friederich, E.T. Peltzer, and F.M. Orr Jr. 1999. Direct experiments on the ocean disposal of fossil fuel $\mathrm{CO}_{2}$. Science 284:943-945, https://doi.org/10.1126/science.284.5416.943.

Brewer, P.G., A.F. Hofmann, E.T. Peltzer, and W. Ussler. 2014a. Evaluating microbial chemical choices: The ocean chemistry basis for the competition between use of $\mathrm{O}_{2}$ or $\mathrm{NO}_{3}^{-}$as an electron acceptor. Deep Sea Research Part / 87:35-42, https://doi.org/ 10.1016/j.dsr.2014.02.002.

Brewer, P.G., and W.J. Kirkwood. 2013. Raman spectroscopy for subsea applications. Pp. 409-433 in Subsea Optics and Imaging. J. Watson and O. Zielinski, eds, Woodhead Publishing.

Brewer, P.G., G. Malby, J.D. Pasteris, S.N. White,

E.T. Peltzer, B. Wopenka, J. Freeman, and M.O. Brown. 2004. Development of a laser Raman 
spectrometer for deep-ocean science. Deep Sea Research Part / 51:739-753, https://doi.org/10.1016/ j.dsr.2003.11.005.

Brewer, P.G., F.M. Orr Jr., G. Friederich, K.A. Kvenvolden, and D.L. Orange. 1998. Gas hydrate formation in the deep sea: In situ experiments with controlled release of methane, natural gas and carbon dioxide. Energy \& Fuels 12:183-188, https://doi.org/10.1021/ef970172q.

Brewer, P.G., and E.T. Peltzer. 2016. Ocean chemistry, ocean warming, and emerging hypoxia. Journal of Geophysical Research 121:3,659-3,667, https://doi.org/10.1002/2016JC011651.

Brewer, P.G., and E.T. Peltzer. 2017. Depth perception: The need to report ocean biogeochemical rates as functions of temperature, not depth. Philosophical Transactions of the Royal Society A, https://doi.org/ 10.1098/rsta.2016.0319.

Brewer, P.G., E.T. Peltzer, G. Friederich, and G. Rehder. 2002. Experimental determination of the fate of rising $\mathrm{CO}_{2}$ droplets in sea water. Environmental Science \& Technology 36:5,441-5,446 https://doi.org/10.1021/es025909

Brewer, P.G., E.T. Peltzer, P. Walz, I. Aya, K. Yamane, R. Kojima, Y. Nakajima, N. Nakayama, P. Haugan, and T. Johannessen. 2005. Deep ocean experiments with fossil fuel carbon dioxide: Creation and sensing of a controlled plume at $4 \mathrm{~km}$ depth. Journal of Marine Research 63:9-33, https://doi.org/10.1357/0022240053693860.

Brewer, P.G., E.T. Peltzer, P.M. Walz, E.K. Coward, L.A. Stern, S.H. Kirby, and J. Pinkston. 2014b. Deepsea field test of the $\mathrm{CH}_{4}$ hydrate to $\mathrm{CO}_{2}$ hydrate spontaneous conversion hypothesis. Energy \& Fue/s 28(11):7,061-7,069, https://doi.org/10.1021/ ef501430h.

Brewer, P.G., E.T. Peltzer, P.M. Walz, and M. Wojciechowicz. 2017. The speciation of water in sea water and in gelatinous marine animals. Marine Chemistry 195:94-104, https://doi.org/10.1016/ j.marchem.2017.05.002

Burdige, D.J. 2007. Preservation of organic matter in marine sediments: Controls, mechanisms, and an imbalance in sediment organic carbon budgets? Chemical Reviews 107:467-485, https://doi.org/ $10.1021 / \mathrm{cr050347q}$

Caldeira, K., M. Akai, P. Brewer, B. Chen, P. Haugan, T. Iwama, P. Johnston, H. Kheshgi, Q. Li, T. Ohsumi, and others. 2005. Ocean storage. Pp. 277-317 in Carbon Dioxide Capture and Storage: A Special Report of IPCC Working Group III. B. Metz and O. Davidson, eds, Cambridge University Press, Cambridge, UK.

Cicerone, R., J. Orr, P.G. Brewer, P. Haugan, L. Merlivat, T. Ohsumi, S. Pantoja, and H.O. Poertner. 2004. The ocean in a high $\mathrm{CO}_{2}$ world. Eos, Transactions American Geophysical Union 85:351-353, https://doi.org/ 10.1029/2004EO370007.

Dunk, R.M., E.T. Peltzer, P. Walz, and P.G. Brewer. 2005. Seeing a deep ocean $\mathrm{CO}_{2}$ enrichment experiment in a new light: Laser Raman detection of dissolved $\mathrm{CO}_{2}$ in seawater. Environmental Science \& Technology 39:9,630-9,636 https://doi.org/10.1021/es0511725.

Gattuso, J.-P., and L. Hansson. 2011. Ocean Acidification. Oxford University Press, $326 \mathrm{pp}$.

Hanisch, C. 1998. The pros and cons of carbon dioxide dumping. Environmental Science \& Technology 32:20A-24A, https://doi.org/10.1021/ es983310e.

Holder, G.D., A.V. Cugini, and R.P. Warzinski. 1995. Modeling clathrate hydrate formation during carbon dioxide injection into the ocean. Environmental Science \& Technology 29:276-278, https://doi.org/ 10.1021/es00001a037.

Kirkwood, W.J., P.M. Walz, E.T. Peltzer, J.P. Barry, R.A. Herlien, K.L. Headley, C. Kecy, G.I. Matsumoto, T. Maughan, T.C. O'Reilly, and others. 2014. Design, construction, operation and performance of a deep-sea free ocean $\mathrm{CO}_{2}$ enrichment (FOCE) experimental system. Deep Sea Research Part / 97:1-9, https://doi.org/10.1016/ j.dsr.2014.11.005.

Kleinberg, R.L. 1996. Well logging. Pp. 4,960-4,969 in Encyclopedia of Nuclear Magnetic Resonance, vol. 8. D.M. Grant and R.K. Harris, eds, Wiley, Chichester.

Kleinberg, R.L., and P.G. Brewer. 2001. Probing gas hydrate deposits. American Scientist 89:244-251.

Kleinberg, R.L., P.G. Brewer, G. Malby, E.T. Peltzer G. Friederich, J. Yesinowski, and C. Flaum. 2003. Seafloor nuclear magnetic resonance assay of methane hydrate in sediment and rock. Journal of Geophysical Research 108(B3), 2137, https://doi.org/10.1029/2001JB000919.

Lee, H., S. Yongwon, Y.-T. Sea, I.L. Moudrakovski, and J.A. Ripmeester. 2003. Recovering methane from solid methane hydrate with carbon dioxide. Angewandte Chemie 115:5,202-5,205, https://doi.org/10.1002/anie.200351489.

Marchetti, C. 1977. On geoengineering and the $\mathrm{CO}_{2}$ problem. Climatic Change 1:59-68, https://doi.org/ 10.1007/BF00162777.

NRC (National Research Council). 2004. Charting the Future of Methane Hydrate Research in the United States. The National Academies Press, Washington, DC, $192 \mathrm{pp}$

Ota, M., T. Saito, T. Aida, M. Watanabe, Y. Sato, R.L. Smith Jr., and H. Inomata. 2007. Macro and microscopic $\mathrm{CH}_{4}-\mathrm{CO}_{2}$ replacement in $\mathrm{CH}_{4}$ hydrate under pressurized $\mathrm{CO}_{2}$. AlChE Journal 53(10):2,715-2,721, https://doi.org/ 10.1002/aic.11294.

Pasteris, J.D., B. Wopenka, J.J. Freeman, P.G. Brewer, S.N. White, E.T. Peltzer, and G. Malby. 2004. Spectroscopic successes and challenges: Raman spectroscopy at $3.6 \mathrm{~km}$ depth in the ocean. Applied Spectroscopy 58(7):195A-208A

Paull, C., and W. Ussler. 2001. History and significance of gas sampling during DSDP and ODP drilling associated with gas hydrates. Pp. 53-65 in Natural Gas Hydrates: Occurrence, Distribution, and Detection. C.K. Paull and W.P. Dillon, eds, American Geophysical Union, Washington, DC, https://doi.org/10.1029/GM124p0053.

Park, Y., D.Y. Kim, J.W. Lee, D.G. Huh, K.P. Park, J. Lee, and H. Lee. 2006. Sequestering carbon dioxide into complex structures of naturally occurring gas hydrates. Proceedings of the Nationa Academy of Sciences of the United States of America 103(34):12,690-12,694, https://doi.org/ 10.1073/pnas.0602251103.

PCAST (President's Council of Advisors on Science and Technology). 1997. Federal Energy Research and Development Agenda for the Challenges of the Twenty-First Century. US Department of Energy, Washington, DC.

Peltzer, E.T., X. Zhang, P.M. Walz, M. Luna, and P.G. Brewer. 2016. In situ Raman measurement of $\mathrm{HS}^{-}$and $\mathrm{H}_{2} \mathrm{~S}$ in sediment pore waters and use of the $\mathrm{HS}^{-}: \mathrm{H}_{2} \mathrm{~S}$ ratio as an indicator of pore water pH. Marine Chemistry 184:32-42, https://doi.org/ 10.1016/j.marchem.2016.05.006

Raman, C.V. 1930. The molecular scattering of light. Nobel Lecture, December 11, 1930, https://www.nobelprize.org/nobel_prizes/physics/ laureates/1930/raman-lecture.pdf.

Reeburgh, W.S. 2007. Oceanic methane biogeochemistry. Chemical Reviews 107:486-513, https://doi.org/10.1021/cr050362v.

Rehder, G., P.G. Brewer, E.T. Peltzer, and G. Friederich. 2002. Enhanced lifetime of methane bubble streams within the deep ocean. Geophysical Research Letters 29(15), https://doi.org/10.1029/ 2001GL013966.

Rehder, G., S.H. Kirby, W.B. Durham, L.A. Stern, E.T. Peltzer, J. Pinkston, and P.G. Brewer. 2004 Dissolution rates of pure methane hydrate and carbon dioxide hydrate in under-saturated seawate at 1000-m depth. Geochimica et Cosmochima Acta 68(2):285-292, https://doi.org/10.1016/ j.gca.2003.07.001.
Rubey, W.W. 1951. Geologic history of seawater: An attempt to state the problem. Bulletin of the Geological Society of America 62:1,111-1,148, https://doi.org/10.1130/0016-7606(1951)62 [1111:GHOSW]2.0.CO;2.

Sillén, L.G. 1961. The physical chemistry of sea water. Pp. 549-581 in Oceanography. M. Sears, ed., American Association for the Advancement of Science, Washington, DC.

Sloan, E.D. 1997. Clathrate Hydrates of Natural Gases. Marcel Dekker, Inc., New York.

Sonnerup, R.E., S. Mecking, and J.L. Bullister. 2013. Transit time distributions and oxygen utilization rates in the Northeast Pacific Ocean from chlorofluorocarbons and sulfur hexafluoride. Deep Sea Research Part / 72:61-71, https://doi.org/10.1016/ j.dsr.2012.10.013.

Stanley, R.H.R., S.C. Doney, W.J. Jenkins, and D.E. Lott. 2012. Apparent oxygen utilization rates calculated from tritium and helium-3 profiles at the Bermuda Atlantic Time-series Study site. Biogeosciences 9:1,969-1,983, https://doi.org/ 10.5194/bg-9-1969-2012.

Sum, A.K., R.C. Burruss, and E.D. Sloan Jr. 1997. Measurement of clathrate hydrates via Raman spectroscopy. The Journal of Physical Chemistry 101:7,371-7,377, https://doi.org/10.1021/ jp970768e.

Tsouris, C., P.G. Brewer, E. Peltzer, P. Walz, D. Riestenberg, L. Liang, and O.R. West. 2004. Hydrate composite particles for ocean carbon sequestration: Field verification. Environmental Science \& Technology 38:2,470-2,475 https://doi.org/10.1021/es034990a.

Tsouris, C., P. Szymcek, P. Taboada-Serrano, S.D. McCallum. P.G. Brewer, E.T. Peltzer, P. Walz, E. Adams, A. Chow, W.K. Johnson, and J. Summers. 2007. Scaled-up injection of $\mathrm{CO}_{2}$-hydrate composite particles. Energy \& Fuels 21:3,300-3,309, https://doi.org/10.1021/ef070197h.

Zhang, X., P. Walz, W.J. Kirkwood, K.C. Hester, W. Ussler, E.T. Peltzer, and P.G. Brewer. 2010. Development and deployment of a deep-sea Raman probe for measurement of pore water geochemistry. Deep Sea Research Part I 57:297-306, https://doi.org/10.1016/j.dsr.2009.11.004.

Zhang, X., K.C. Hester, W. Ussler, P.M. Walz, E.T. Peltzer, and P.G. Brewer. 2011. In situ Ramanbased measurements of high dissolved methane concentrations in hydrate-rich ocean sediments. Geophysical Research Letters 38, L08605, https://doi.org/10.1029/2011GL047141.

\section{ACKNOWLEDGMENTS}

This work was supported by a grant to MBARI from the David and Lucile Packard Foundation. All data supporting the work reported here are directly associated with the original publications or can be accessed from open MBARI databases, and by request to the authors.

\section{AUTHORS}

Peter G. Brewer (brpe@mbari.org) is Senior Scientist, Edward T. Peltzer is Senior Research Specialist, Peter M. Walz is Research Specialist, and William J. Kirkwood is Senior Research and Development Engineer, all at the Monterey Bay Aquarium Research Institute, Moss Landing, CA, USA

\section{ARTICLE CITATION}

Brewer, P.G., E.T. Peltzer, P.M. Walz, and W.J. Kirkwood. 2017. Creating the art of deepsea experimental chemistry with MBARI ROVs. Oceanography 30(4):48-59, https://doi.org/10.5670/ oceanog.2017.423. 